\title{
Model Pembelajaran Kooperatif Co-Op Co-Op dengan Pendekatan Predict- Observe-Explain untuk Meningkatkan Kemampuan Pemecahan Masalah Matematis
}

\author{
Sri Maryanti ${ }^{*}$ \\ 1 Universitas Islam Negeri Raden Intan Lampung. Jalan Endro Suratmin, Sukarame, Bandar \\ Lampung35133, Indonesia. \\ *Corresponding Author. E-mail: srimaryanti2109@gmail.com
}

Received : 13-07-2018; Revised : 09-08-2018; Accepted : 14-08-2018

\begin{abstract}
Abstrak
Tujuan dari penelitian ini adalah untuk mengetahui apakah penerapan model pembelajaran kooperatif $\mathrm{Co}-\mathrm{Op}$ Co-Op dengan pendekatan POE (predict-observe-explain) dapat meningkatkan kemampuan pemecahan masalah matematis siswa . Penelitian ini merupakan penelitian Quasi Eksperimental Design dan Desain peneliti yang digunakan dalam penelitian ini adalah desain kelompok kontrol pretest-posttest, dengan teknik Random Sampling. Uji hipotesis yang digunakan dalam penelitian ini yaitu uji-t. Dari hasil penelitian uji statistik menunjukkan bahwa nilai dari $t_{\text {hitung }}$ berdasarkan perhitungan yang diperoleh $t_{\text {hitung }}=5,5009$, dan $t_{\text {tabel }}=$ 2,001 sehingga $t_{\text {hitung }}>t_{\text {tabel}}$, sehingga berdasarkan perhitungan tersebut dapat disimpulkan bahwa model pembelajaran kooperatif $\mathrm{Co}-\mathrm{Op} \mathrm{Co}-\mathrm{Op}$ dengan pendekatan $\mathrm{POE}$ (predict-observeexpalin) dapat meningkatkan kemampuan pemecahan masalah matematis siswa.

Kata kunci: Kooperatif Co-Op Co-Op, predict observe-explain, Kemampuan Pemecahan Masalah Matematis.
\end{abstract}

\begin{abstract}
The purpose of this study was to find our whether cooperative learning model Co-Op Co-Op approach POE (predict-observe-explain) can increase the ability troubleshooting mathematical students. This research is a research Quasi Eksperimental Design and design researchers used in this study is the design of the control group pretest-postest, with a technique random class. Hypothesis test used in this research is t-test. From the results of statistical tests showed that the value of t_hitung based on the calculation obtained t_hitung $=5.500869$, and t_tabel $=2.001$ so that t_hitung $>$ t_tabel. So based on these calculation can be concluded that the model cooperative learning CO-Op Co-Op approach POE (predict-observe-explain) can increase the ability troubleshooting mathematical students.
\end{abstract}

Keywords: Cooperative Learning Model Co-Op Co-Op, predict-observe-explain Approach, Mathematical Problem Solving Abilities.

\section{PENDAHULUAN}

Pendidikan merupakan proses mengubah diri kita dari hal terkecil hingga suatu hal yang besar dan di dalam prosesnya kita juga akan mengalami perubahan yang signifikan dalam segi kualitas diri. Adanya masalah dalam kehidupan manusia akan menjadikan manusia semakin maju dan berkembang dalam proses berpikirnya. Oleh karena itu, tidaklah mengherankan bahwa kebutuhan untuk dapat mengatasi masalah dalam hidup seseorang menjadi sangat penting. Kemampuan pemecahan masalah adalah kemampuan yang harus dimiliki siswa dalam upaya menyelesaikan permasalahan matematika dengan menggunakan langkah-langkah pemecahan masalah (Lisna Agustina, 
2016). Pentingnya penelitian ini dilakukan agar siswa dapat menunjukkan kemampuan belajar secara mandiri sesuai potensi, mampu memecahkan masalah dalam kehidupan sehari-hari, dan dapat menunjukkan kemampuan berpikir kritis, logis, kreatif dan inovatif (Mujib, 2016), serta membuat siswa menjadi lebih aktif dan berfikir kreatif dalam berdiskusi terutama dalam pemecahan masalah matematis untuk menemukan suatu ide atau pemecahan masalah matematika berdasarkan pengalaman dan pengetahuannya sendiri serta membuat siswa mempunyai tanggung jawab menguasai pelajaran untuk di presentasikan atau diajarkan kepada teman-teman nya baik teman sesama kelompok maupun teman antar kelompok nya.

Permasalahan ini disebabkan oleh model pembelajaran yang kurang tepat dalam pembelajaran matematis (Netriwati, 2016; Purwasih, 2015). Salah satu alternatif model pembelajaran yang mampu memberikan motivasi dan minat belajar siswa adalah dengan menggunakan model pembelajaran kooperatif $\mathrm{Co}-\mathrm{Op}$ Co-Op. Co-Op Co-Op adalah Usaha pertama dengan menanamkan rasa percaya diri siswa yang dilakukan pada kegiatan pembelajaran yang ada kesesuaiannya dengan kehidupan sehari-hari, berusaha menarik dan menumbuhkan/memunculkan berbagai kemungkinan argumentasi terhadap permasalahan yang diajukan berdasarkan pengalaman siswa (Slavin, 2015). Model pembelajaran ini memiliki beberapa langkah proses pembelajarannya dimana terdapat pembelajaran kooperatif dalam pelaksanaanya. Salah satu pendekatan pembelajaran yang dirasa cocok untuk di satukan dengan $\mathrm{Co}-\mathrm{Op} \mathrm{Co}-\mathrm{Op}$ adalah Pendekatan POE (Predict-ObserveExplain). POE termasuk salah satu pendekatan pembelajaran yang bisa membuat siswa lebih kreatif dalam menggali pengetahuannya sendiri sesuai dengan faham konstruktivisme (Vida Indriana; Nurdin Arsyad; Usman Mulbar, 2015). Jadi Model pembelajaran kooperatif $\mathrm{Co}-\mathrm{Op} \quad \mathrm{Co}-\mathrm{Op}$ dengan Pendekatan POE (Predict-ObserveExplain) ini membuat siswa menjadi lebih aktif dan berfikir kreatif dalam berdiskusi terutama dalam pemecahan masalah matematis untuk menemukan suatu ide atau pemecahan masalah matematika berdasarkan pengalaman dan pengetahuannya sendiri. Dan alasan kenapa kemampuan pemecahan masalah matematis ini yang diteliti karena menurut wawancara terhadap salah satu guru matematika didapat bahwa kurangnya siswa dalam kemampuan pemecahan masalah matematisnya.

Berdasarkan penelitian sebelumnya bahwa Pembelajaran Kooperatif Co-Op Co-Op Dengan Pendekatan Open-Ended untuk Meningkatkan Kemampuan Pemecahan Masalah Matematis Siswa SMA (Isnaini Mahuda, 2017). Penelitian lainnya yaitu Penerapan model cooperative learning tipe $\mathrm{Co}-\mathrm{Op} \mathrm{Co}-\mathrm{Op}$ disertai metode eksperimen untuk meningkatkan aktivitas dan hasil belajar siswa kelas VIII pada materi teorema pytagoras di SMP Negeri 2 Rambipuji Tahun Pelajaran 2012/2013 (Dewi; Titik Sugiarti; Suharto, 2013). Berdasarkan pembahasan diatas dapat disimpulkan bahwa perbedaan penelitian ini dengan penelitian sebelumnya yaitu model pembelajaran yang digunakan adalah model pembelajaran kooperatif $\mathrm{Co}-\mathrm{Op} \mathrm{Co}$ $O p$ dengan pendekatan Open-Ended serta model pembelajaran kooperatif $\mathrm{Co}-\mathrm{Op} \mathrm{Co}$ $O p$ disertai metode eksperimen sedangkan pada penelitian ini menggunakan model pembelajaran kooperatif $\mathrm{Co}-\mathrm{Op} \quad \mathrm{Co}-\mathrm{Op}$ dengan pendekatan POE (predict-observeexplain). Penelitian berikutnya yaitu bahwa Penerapan Pendekatan Pembelajaran POE (Predict-ObserveExplain) Untuk Meningkatkan 
Kemampuan Berpikir Kreatif Siswa Kelas XI IPA-1 SMAN 22 Makassar (Vida Indriana; Nurdin Arsyad; Usman Mulbar, 2015). Dilain pihak, penggunaan pendekatan POE (predict-observe-explain) berpengaruh terhadap hasil belajar siswa (Andari Puji Astuti; Subiyanto; Ahmad Binadja, 2013). Berdasarkan pembahasan diatas perbedaan penelitian ini dengan penelitian sebelumnya yaitu penelitian sebelumnya menghasilkan kemampuan berpikir kreatif matematis siswa SMA serta hasil belajar siswa melalui pembelajaran pendekatan POE (predict-observe-explain) sedangkan pada penelitian ini akan menghasilkan kemampuan pemecahan masalah matematis siswa SMP melalui pendekatan POE (predict-observe-explain). Selain itu penelitian lainnya menghasilkan peningkatan kemampuan pemecahan masalah matematis siswa dengan menerapkan strategi pembelajaran inkuiri (Fimatesa Windari; Fitrani Dwina; Suherman, 2014), menggunakan pendekatan Problem Posing (Indah Puspita Sari, 2015), menerapkan model Problem Based Intruction (Rahmat Fitra; Hajidin; B.I Anshari, 2016), menggunakan pembelajaran berbasis masalah (Irma Sari Daulay, 2017), menerapkan strategi pemecahan masalah (Dina Agustina; Edwin Musdi; Ahmad Fauzan, 2014) serta menggunakan model pembelajaran Problem Based Learning (Marojahan Panjaitan; Sri R Rajagukguk, 2017) . Kemudian penelitian berikutnya bahwa peningkatan kemampuan pemecahan masalah matematis dapat dibuktikan dengan metode pembelajaran inkuiri berbantuan softwere algebrator. Hal ini ditunjukkan dengan peningkatan tiap indikator kemampuan pemecahan masalah matematis dalam pembelajaran matematika (Yulian, 2016). Berdasarkan pembahasan diatas perbedaan penelitian ini dengan penelitian sebelumnya yaitu penelitian sebelumnya menghasilkan kemampuan pemecahan matematis siswa dengan menggunakan strategi pembelajaran inkuiri, pendekatan Problem Posing, model Problem Based Intruction, pembelajaran berbasis masalah, strategi pemecahan masalah, model pembelajaran Problem Based Learning serta menggunakan metode pembelajaran inkuiri berbantuan softwere algebrator sedangkan pada penelitian ini menggunakan model pembelajaran kooperatif $\mathrm{Co}-\mathrm{Op}$ Co-Op dengan pendekatan POE (predict-observeexplain).

Berdasarkan penelitian sebelumnya yang telah dipaparkan, maka dalam penelitian ini, peneliti tertarik melakukan sebuah penelitain dengan menggunakan kemampuan pemecahan masalah matematis melalui model pembelajaran kooperatif $\mathrm{Co}-\mathrm{Op} \quad \mathrm{Co}-\mathrm{Op}$ dengan pendekatan POE (predict-observe-explain) untuk mengatasi permasalahan kemampuan pemecahan masalah matematis siswa. Dengan tujuan untuk mengetahui apakah penerapan model pembelajaran kooperatif $\mathrm{Co}-\mathrm{Op} \quad \mathrm{Co}-\mathrm{Op}$ dengan pendekatan POE (Predict-ObserveExplain) dapat meningkatkan kemampuan pemecahan masalah matematis siswa.

Penelitian ini akan berbeda dengan penelitian yang sebelumnya dimana model pembelajaran kooperatif $\mathrm{Co}-\mathrm{Op} \mathrm{Co}$ $O p$ dengan pendekatan POE (predictobserve-explain) melalui kemampuan pemecahan masalah matematis siswa. Selain itu, model pembelajaran kooperatif Co-Op Co-Op dengan pendekatan POE (predict-observe-explain) disinergikan dengan sebuah kemampuan pemecahan masalah matematis yang lain. Di sini peneliti melakukan modifikasi pada model kooperatif $\mathrm{Co}-\mathrm{Op} \mathrm{Co}-\mathrm{Op}$ dengan pendekatan POE (predict-observeexplain).

\section{METODE PENELITIAN}

Metode dalam penelitian ini adalah Quasi Eksperimental Design. 
Desain peneliti yang digunakan dalam penelitian ini adalah desain kelompok kontrol pretest-posttest.

\section{Tabel 1. Desain Faktorial Penelitian}

\begin{tabular}{cccc} 
Kelompok & Pretest & Treatmen & Postest \\
Eksperimen & $T_{1}$ & $X_{1}$ & $T_{2}$ \\
Kontrol & $O_{1}$ & $X_{2}$ & $O_{2}$ \\
\hline
\end{tabular}

Sampel yang diambil dalam penelitian ini yaitu dengan menggunakan tehnik Random Sampling. Data dikumpulkan melalui Metode wawancara, dokumentasi dan Tes. Instrumen bantu dalam penelitian ini adalah soal tes yang digunakan sebanyak 5 butir soal berbentuk soal uraian atau essay. Tehnik analisis data yang digunakan dalam penelitian ini berupa uji prasyarat terhadap data tersebut meliputi uji normalitas dengan menggunakan metode Liliefors. Uji normalitas dilakukan untuk mengetahui apakah sampel yang diambil dalam penelitian berdistribusi normal atau tidak. Uji kenormalan yang digunakan peneliti adalah uji Liliefors. Uji Liliefors merupakan salah satu uji yang sering digunakan untuk menguji kenormalan data (Novalia and M.Syazali, 2014).

Rumus Uji Liliefors sebagai berikut:

$$
\begin{aligned}
\mathrm{L}_{\text {hitung }} & =\operatorname{Max}|F(z)-S(z)| \\
\mathrm{L}_{\text {tabel }} & =\mathrm{L}_{(\alpha, n)}
\end{aligned}
$$

Dengan hipotesis:

$H_{o} \quad$ : Data mengikuti sebaran normal

$H_{1}$ : Data tidak mengikuti sebaran normal

Kesimpulan: Jika $L_{\text {hitung }} \leq L_{\text {tabel }}$, maka $H_{o}$ diterima.

Uji prasyarat selanjutnya yaitu Uji homogenitas dengan mengunakan metode Bartlett. Pengujian homogenitas adalah pengujian mengenai sama tidaknya variansi-variansi dua buah distribusi atau lebih. Uji homogenitas dapat dilakukan dengan berbagai cara yaitu uji kesamaan varians, dan uji
Bartlett. Uji homogenitas yang akan dibahas dalam tulisan ini adalah Uji Bartlett. Uji Bartlett dapat digunakan untuk menguji homogenitas dari 2 kelompok data atau lebih. Rumus Uji Bartlett sebagai berikut:

$$
\begin{aligned}
& \chi_{\text {hitung }}^{2}=(10)\left\{\mathrm{B}-\sum_{i=1}^{k} \mathrm{dk} \operatorname{LogS}^{2}\right\}, \\
& \chi_{\text {tabel }}=\chi^{2}{ }_{(\alpha, k-1)} .
\end{aligned}
$$

Dengan hipotesis:

$$
\begin{aligned}
& H_{0} \text { : Data homogen } \\
& H_{1} \text { : Data tidak homogen }
\end{aligned}
$$

Penarikan kesimpulan untuk uji Bartlett sebagai berikut: Jika $\chi^{2}$ hitung $\leq$ $\chi^{2}$ tabel maka $\mathrm{H}_{0}$ diterima.

Berdasarkan hasil pengujian, apabila diperoleh perbedaan nilai rata-rata kemampuan pemecahan masalah matematis, berarti ada peningkatan yang signifikan maka kemudian dihitung dengan $\mathrm{N}$-Gain score untuk mengetahui kriteria peningkatan yang terjadi. Perhitungan $N$-Gain menunjukkan bahwa perlakuan yang diberikan berpengaruh dalam kategori sedang terhadap peningkatan kemampuan pemecahan masalah matematis. Untuk perhitungan gain yang dinormalisasi digunakan persamaan:

$$
N \text {-Gain }=\frac{(\text { skor posttest })-(\text { skor } \text { pretest })}{(\text { skor maksimum })-(\text { skor pretest })}
$$

Tingkat perolehan skor gain ternormalisasi dikelompokkan kedalam tiga kategori menurut Nunun Elida (Elida, 2012):

Tabel 2. Klasifikasi Interpretasi Nilai Gain Ternormalisasi

\begin{tabular}{cc} 
Nilai N-Gain & Interpretasi \\
$\mathrm{g}>0,70$ & Tinggi \\
$\mathbf{0 , 7 0} \leq \mathrm{g} \leq 0,30$ & Sedang \\
$\mathrm{g}<0,30$ & Rendah \\
\hline
\end{tabular}

Berdasarkan penelitian ini peneliti menggunakan nilai gain interpretasi sedang yaitu $0,70 \leq \mathrm{g} \leq 0,30$. Analisis data skor gain ternormalisasi dilakukan 
untuk menguji hipotesis, jika kemampuan awal kelompok eksperimen dan kelompok kontrol berbeda secara signifikan.

Uji sampel berasal dari populasi yang berdistribusi normal dan homogen, maka dilanjutkan pengujian hipotesis teknik statistik melalui Uji-t (Uji Perbandingan)

Hipotesis:

1) $H_{0}: \mu_{1} \leq \mu_{2}$ (Nilai rata-rata kemampuan pemecahan masalah matematis siswa yang menggunakan Model pembelajaran kooperatif $\mathrm{Co}$ $O p$ Co-Op dengan pendekatan $\mathrm{POE}$ (predict-observe-explain) kurang dari atau sama dengan nilai rata-rata kemampuan pemecahan masalah matematis siswa yang menggunakan model pembelajaran konvensional).

2) $H_{1}: \mu_{1}>\mu_{2}$ (Nilai rata-rata kemampuan pemecahan masalah matematis siswa yang menggunakan Model pembelajaran kooperatif $\mathrm{Co}$ $O p$ Co-Op dengan pendekatan POE (predict-observe-explain) lebih dari nilai rata-rata kemampuan pemecahan masalah matematis siswa yang menggunakan model pembelajaran konvensional).

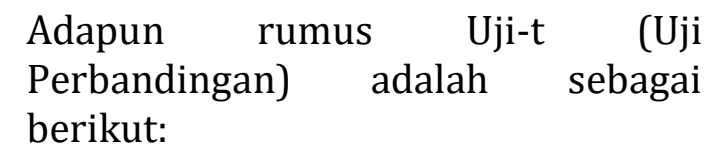

$$
=\frac{t_{\text {hitung }}}{\sqrt{\frac{\left(\mathrm{n}_{1}-1\right) \mathrm{s}_{1}{ }^{2}+\left(\mathrm{n}_{2}-1\right) \mathrm{s}_{2}{ }^{2}}{\left(\mathrm{n}_{1}+\mathrm{n}_{2}-2\right)}\left(\frac{1}{\mathrm{n}_{1}}+\frac{1}{\mathrm{n}_{2}}\right)}}
$$

Keterangan:

$\overline{\mathrm{X}}_{1}=$ Rata-rata nilai kelas eksperimen

$\overline{\mathrm{X}}_{2}=$ Rata-rata nilai kelas kontrol

$\mathrm{n}_{1}=$ Banyaknya siswa kelas eksperimen

$\mathrm{n}_{2}=$ Banyaknya siswa kelas kontrol

$\mathrm{S}_{1}{ }^{2}=$ Varians kelas eksperimen

$\mathrm{S}_{2}{ }^{2}=$ Varians kelas control

\section{HASIL DAN PEMBAHASAN}

Data kemampuan pemecahan masalah matematis siswa pada mata pelajaran matematika materi garis singgung lingkaran dapat disajikan pada Tabel 3. di bawah ini:

\begin{tabular}{|c|c|c|c|c|c|c|c|}
\hline \multirow[t]{2}{*}{ Kelas } & \multirow[t]{2}{*}{$X_{M a k}$} & \multirow[t]{2}{*}{$X_{M i n}$} & \multicolumn{3}{|c|}{$\begin{array}{c}\text { Ukuran Tendensi } \\
\text { Sental }\end{array}$} & \multicolumn{2}{|c|}{ Ukuran Variansi Kelompok } \\
\hline & & & $\bar{X}$ & Me & Mo & $\mathbf{R}$ & $\mathbf{S}$ \\
\hline Eksperimen & 75 & 25 & 43,87 & 42,5 & 25 & 50 & 15,16 \\
\hline Kontrol & 70 & 10 & 37,52 & 43 & 45 & 60 & 14,65 \\
\hline
\end{tabular}

Tabel 3. Deskripsi Data Amatan Kemampuaan Pemecahan Masalah Matematis Siswa

Berdasarkan Tabel 3. tersebut, diketahui bahwa terdapat perbedaan nilai rata-rata kemampuan pemecahan masalah matematis siswa antara kelas eksperimen dan kelas kontrol. Kelas ekperimen memiliki rata-rata kemampuan pemecahan masalah matematis yang lebih tinggi dari kelas kontrol.

Berdasarkan data yang telah diperoleh, hasil uji prasyarat yaitu uji normalitas menunjukkan bahwa awal kemampuan pemecahan masalah matematis siswa pada kelas eksperimen adalah skor pretest kelas eksperimen sebesar 43,8667 dengan $\boldsymbol{L}_{\text {hitung }}=$ 0,1539 dan $L_{\text {tabel }}=\mathbf{0 , 1 5 9 0}$ hal ini menunjukan bahwa $\boldsymbol{L}_{\text {hitung }}<\boldsymbol{L}_{\text {tabel }}$ sehingga dapat disimpulkan data berdistribusi normal. Dan kelas kontrol adalah skor pretest kelas kontrol sebesar 37,5161 dengan $\boldsymbol{L}_{\text {hitung }}=\mathbf{0 , 1 4 3 5}$ dan 


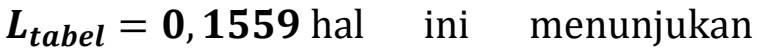
bahwa $\boldsymbol{L}_{\text {hitung }}<\boldsymbol{L}_{\text {tabel }}$ sehingga dapat disimpulkan data berdistribusi normal. Uji normalitas peningkatan kemampuan pemecahan masalah matematis siswa kelas eksperimen adalah skor postest kelas eksperimen sebesar 75,7667 dengan $\quad L_{\text {hitung }}=\mathbf{0 , 1 3 8 9}$ dan $\boldsymbol{L}_{\text {tabel }}=\mathbf{0 , 1 5 9 0}$ sedangkan skor $N$-gain kelas eksperimen sebesar 0,54950 dengan $\quad L_{\text {hitung }}=\mathbf{0 , 1 1 0 3}$ dan $\boldsymbol{L}_{\text {tabel }}=\mathbf{0 , 1 5 9 0}$ hal ini menunjukan bahwa $\boldsymbol{L}_{\text {hitung }}<\boldsymbol{L}_{\text {tabel }}$ sehingga dapat disimpulkan data berdistribusi normal. Dan kelas kontrol adalah skor postest kelas kontrol sebesar 55,1934 dengan $\boldsymbol{L}_{\text {hitung }}=\mathbf{0}, \mathbf{1 1 8 2}$ dan $\quad \boldsymbol{L}_{\text {tabel }}=$ 0,1559 sedangkan skor $N$-gain kelas kontrol sebesar 0,28939 dengan $L_{\text {hitung }}=0,1027$ dan $\quad L_{\text {tabel }}=0,1559$ hal ini menunjukan bahwa $\boldsymbol{L}_{\text {hitung }}<$ $\boldsymbol{L}_{\text {tabel }}$ sehingga dapat disimpulkan data berdistribusi normal. Berikut hasil rekapitulasi perhitungan uji normalitas kemampuan pemecahan masalah matematis pada kelas eksperimen dan kelas kontrol. Hasil uji normalitas ada dapat dilihat pada Tabel 4 .

Tabel 4. Hasil Perhitungan Uji Normalitas

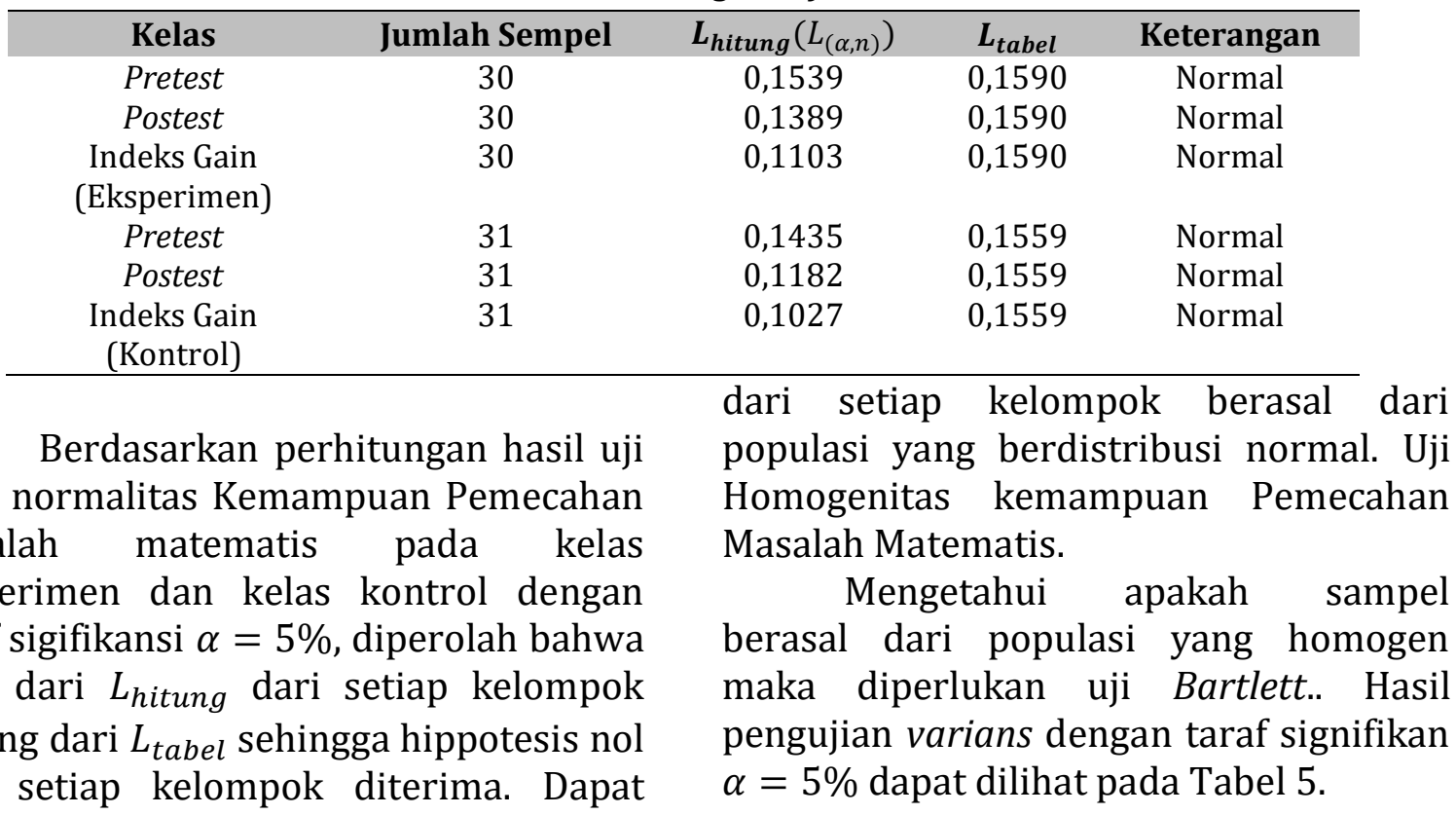
disimpulkan bahwa data yang diperoleh

Tabel 5. Hasil Perhitungan Uji Kesamaan Dua Varians

\begin{tabular}{cccccc}
\hline Kelas & Jumlah Sempel & Varians & $\boldsymbol{X}_{\text {hitung }}^{2}$ & $\boldsymbol{X}_{\text {tabel }}^{2}$ & Keterangan \\
Eksperimen & 30 & 229,9126 & 0,031 & 3,841 & Homogen \\
$\quad$ Kontrol & 31 & 214,7247 & & & \\
(pretest) & & & & & \\
Eksperimen & 30 & 171,978 & 0,631 & 3,841 & Homogen \\
$\quad$ Kontrol & 31 & 229,028 & & & \\
$\begin{array}{c}\text { (Postest) } \\
\text { Eksperimen }\end{array}$ & 30 & 0,0433 & & & \\
$\quad$ Kontrol & 31 & 0,0242 & & & \\
(N-gain) & & & & & \\
\hline
\end{tabular}


Berdasarkan hasil perhitungan skor Peningkatan Kemampuan Pemahaman konsep matematis diperoleh $X_{\text {hitung }}^{2}=2,4854$ dan $X_{\text {tabel }}^{2}=3,841$. Menunjukan bahwa $X_{\text {hitung }}^{2}<X_{\text {tabel }}^{2}$ dengan hal ini dapat disimpulkan bahwa $H_{0}$ diterima atau sempel berasal dari populasi yang memiliki varians sama. Untuk menguji perbedaan Kemampuan Pemahaman konsep matematis peserta didik digunakan rumus uji-t, karena data yang diperoleh berdistribusi normal dan memiliki nilai varians sama, maka rumus yang digunakan sebagai berikut dengan besaran $d k=n_{1}+n_{2}-2$, harga $t_{\text {tabel }}$ dihitung $d k=30+31-2=59$ maka harga $t_{\text {tabel }}=2,001$ dengan taraf signifikansi $5 \%$. Hasil perhitungan dapat dilihat pada Tabel 6.

Tabel 6. Hasil Perhitungan Uji

\begin{tabular}{cccccc}
\hline Kelas & Jumlah Sempel & Rata-Rata $(\boldsymbol{x})$ & $\boldsymbol{t}_{\boldsymbol{t a b l e}}\left(\boldsymbol{t}_{(\boldsymbol{a}, \boldsymbol{d} \boldsymbol{b})}\right)$ & $\boldsymbol{t}_{\text {hitung }}$ & Keterangan \\
Eksperimen & 30 & 0,54950 & 2,001 & 5,5009 & Terima $H_{1}$ \\
Kontrol & 31 & 0,28939 & & & \\
\hline
\end{tabular}

Berdasarkan perhitungan diperoleh $t_{\text {hitung }}=5,5009$ sehingga $t_{\text {hitung }}>t_{\text {table }}$, dengan kata lain tolak $H_{0}$. Dengan artian dapat disimpulkan bahwa terdapat peningkatan secara signifikan antara kemampuan pemecahan masalah matematis siswa kelas eksperimen dan kelas kontrol. Dengan demikian, setelah diterapkan model pembelajaran kooperatif $\mathrm{Co}-\mathrm{Op} \quad \mathrm{Co}-\mathrm{Op}$ dengan pendekatan POE (predict-observe-explain) terdapat peningkatan terhadap kemampuan pemecahan masalah matematis siswa. Hal ini menunjukkan bahwa model pembelajaran kooperatif Co-Op Co-Op dengan pendekatan POE (predict-observe-explain) memiliki pengaruh yang signifikan terhadap peningkatan kemampuan pemecahan masalah matematis siswa.

Hasil penelitian ini menunjukkan bahwa peningkatan kemampuan pemecahan masalah matematis menggunakan model pembelajaran kooperatif $\mathrm{Co}-\mathrm{Op} \quad \mathrm{Co}-\mathrm{Op}$ dengan pendekatan POE (predict-observe-explain) lebih baik terhadap peningkatan kemampuan pemecahan masalah matematis dengan model pembelajaran konvensional yang artinya bahwa model pembelajaran kooperatif $\mathrm{Co}-\mathrm{Op}$ Co-Op dengan pendekatan POE (predict- observe-explain) dapat meningkatkan kemampuan pemecahan masalah matematis siswa . Hal ini terbukti dalam penelitian sebelumnya bahwa Model Pembelajaran Kooperatif $\mathrm{Co}-\mathrm{Op}$ Co-Op dengan Pendekatan Open-Ended dapat Meningkatkan Kemampuan Pemecahan Masalah Matematis Siswa SMA dengan hasil yang dinyatakan bahwa penggunaan model pembelajaran kooperatif $\mathrm{Co}-\mathrm{Op} \quad \mathrm{Co}-\mathrm{Op}$ dengan Pendekatan Open-Ended lebih baik dibandingkan dengan menggunakan model pembelajaran kooperatif $\mathrm{Co}-\mathrm{Op} \mathrm{Co}$ Op (Isnaini Mahuda, 2017). Penelitian lainnya mengungkapkan bahwa model cooperative learning tipe $\mathrm{Co}-\mathrm{Op} \mathrm{Co}-\mathrm{Op}$ disertai metode eksperimen. Model ini dapat meningkatkan aktivitas dan hasil belajar siswa dan layak digunakan sebagai model pembelajaran (Dewi; Titik Sugiarti; Suharto, 2013). Kemudian Penelitian berikutnya menjelaskan bahwa Pendekatan pembelajaran POE (PredictObserve-Explain). Pendekatan ini dapat Meningkatkan Kemampuan Berpikir Kreatif dan layak digunakan sebagai pendekatan dalam pembelajaran. Dilain pihak penggunaan pendekatan POE (Predict-Observe-Explain) dapat meningkatkan kemampuan pemecahan masalah matematis siswa (Vida Indriana; Nurdin Arsyad; Usman Mulbar, 2015) 
serta penggunaan pendekatan POE (predict-observe-explain) berpengaruh terhadap hasil belajar siswa (Andari Puji Astuti; Subiyanto; Ahmad Binadja, 2013). Penelitian lainnya mengungkapkan bahwa peningkatan kemampuan pemecahan masalah matematis dapat dibuktikan dengan strategi pembelajaran inkuiri (Fimatesa Windari; Fitrani Dwina; Suherman, 2014), menggunakan pendekatan Problem Posing (Indah Puspita Sari, 2015), menerapkan model Problem Based Intruction (Rahmat Fitra; Hajidin; B.I Anshari, 2016), menggunakan pembelajaran berbasis masalah (Irma Sari Daulay, 2017), menerapkan strategi pemecahan masalah (Dina Agustina; Edwin Musdi; Ahmad Fauzan, 2014), menggunakan model pembelajaran Problem Based Learning (Marojahan Panjaitan; Sri R Rajagukguk, 2017) serta dengan menggunakan metode pembelajaran inkuiri berbantuan softwere algebrator. Hal ini ditunjukkan dengan peningkatan tiap indikator kemampuan pemecahan masalah matematis dalam pembelajaran matematika (Yulian, 2016). Dari pembahasan di atas dapat disimpulkan bahwa hasil dari penelitian ini yaitu dengan menggunakan model pembelajaran kooperatif $\mathrm{Co}-\mathrm{Op}$ Co-Op dengan pendekatan POE (predict-observeexplain) dapat meningkatkan kemampuan pemecahan masalah matematis siswa.

\section{KESIMPULAN DAN SARAN}

Berdasarkan hasil analisis data yang diperoleh hasil peneliti dan pembahasan yang diuraikan diatas dapat disimpulkan bahwa terdapat peningkatan kemampuan pemecahan masalah matematis siswa menggunakan model pembelajaran kooperatif $\mathrm{Co}-\mathrm{Op}$ Co-Op dengan pendekatan POE (predict-observeexplain). Dengan kata lain model pembelajaran kooperatif $\mathrm{Co}-\mathrm{Op}$ Co-Op dengan pendekatan POE (predict-observeexplain) ini dapat meningkatkan kemampuan pemecahan masalah matematis siswa MTs pada pelajaran garis singgung lingkaran dan secara umum siswa menunjukkan sikap yang positif terhadap pembelajaran dengan model kooperatif $\mathrm{Co}-\mathrm{Op}$ Co-Op dengan pendekatan POE (predict-observeexplain).

Memperhatikan hasil dan kesimpulan penelitian, peneliti memberikan beberapa saran yang dapat peneliti kemukakan, diantaranya: (1) Model pembelajaran kooperatif Co-Op CoOp dengan pendekatan POE (predictobserve-explain) dapat dijadikan sebagai salah satu alternatif pembelajaran matematika untuk meningkatkan kemampuan pemecahan masalah matematis siswa. (2) Guru sebaiknya mempertimbangkan topik-topik matematika yang sesuai untuk diajarkan menggunakan model pembelajaran kooperatif Co-Op Co-Op dengan pendekatan POE (predict-observeexplain). (3) Bagi para peneliti, diharapkan pada peneliti dapat mengembangkan penelitian untuk variabel atau model pembelajaran lainyang sejenis sehingga dapat menambah wawasan dan kualitas pendidikan yang lebih baik, terkhusus pada mata pelajaran matematika.

\section{DAFTAR PUSTAKA}

Agustina, Dina, et al. "Penerapan Strategi Pemecahan Masalah Untuk Meningkatkan Kemampuan Pemecahan Masalah Matematis Siswa Kelas VIII SMP Negeri 7 Padang." Jurnal Pendidikan Matematika, vol. 3, no. 2, 2014, h. 20-24.

Agustina, Lisna. "Upaya Meningkatkan Pemahaman Konsep dan Pemecahan Masalah Matematika Siswa SMP Negeri 4 Sipirok Kelas VII Melalui Pendekatan Matematika Realistik ." Jurnal Eksakta, vol. 1, no. 2, 2016, h. 3. 
Astuti, Andari Puji, et al. "Pengaruh Penggunaan Pendekatan POE (Predict-Observe-Explain) Bervisi Sets Pokok Bahasan Reaksi Redoks." JPS, vol. 1, no. 1, 2013, h. 46-52.

Daulay, Irma Sari. "Peningkatan Pemecahan Masalah Matematis Dan Motivasi Belajar Melalui Pembelajaran Berbasis Masalah." Jurnal Pendidikan Dan Kependidikan, vol. 2, no. 2, 2017, h. 81-99.

Dewi, et al. "Penerapan Model Cooperative Learning Tipe $\mathrm{Co}-\mathrm{Op}$ Co-Op Disertai Metode Eksperimen Untuk Meningkatkan Aktivitas Dan Hasil Belajar Siswa Kelas VIII Pada Materi Teorema Pytagoras Di SMP Negeri 2 Rambipuji Tahun Pelajaran 2012/2013." Jurnal Kadikma, vol. 4, no. 3, 2013, h. 3342.

Elida, N. "Meningkatkan Kemampuan Komunikasi Matematik Siswa Sekolah Menengah Pertama Melalui Pembelajaran Think-TalkWrite (TTW)". Jurnal Ilmiah Program Studi Matematika STKIP Siliwangi Bandung, vol. 1, no. 2, 2013, h. 159.

Fitra, Rahmat, et al. "Peningkatan Kemampuan Pemecahan Masalah Siswa SMK Melalui Model Problem Based Intruction (PBI)." Jurnal Didaktik Matematika, vol. 3, no. 2, 2016, h. 35-41.

Indriani, Vida, et al. "Penerapan Pendekatan Pembelajaran POE (Predict-Observe-Explain) Untuk Meningkatkan Kemampuan Berpikir Kreatif Siswa Kelas XI IPA-1 SMAN 22 Makassar." Jurnal Daya Matematis, vol. 3, no. 1, 2015, h. 51-62.

Mahuda, Isnaini. "Pembelajaran Kooperatif Co-Op Co-Op Dengan Pendekatan Open-Ended untuk Meningkatkan Kemampuan
Pemecahan Masalah Matematis Siswa SMA." JPPM, vol. 10, no. 2, 2017, h. 31-39.

Mujib. "Mengembangkan Kemampuan Berfikir Kritis Melalui Metode Pembelajaran Improve". Aljabar: Jurnal Pendidikan Matematika, vol. 7, no. 1, 2016, h. 167-80.

Netriwati. " Analisis Kemampuan Mahasiswa dalam Pemecahan Masalah Matematis menurut Teori Polya". Aljabar: Jurnal Pendidikan Matematika, vol. 7, no. 2, 2016, h. 181-190.

Novalia, and M.Syazali. Olah Data Penelitian Pendidikan. Bandar Lampung: Aura, 2014.

Panjaitan, $\mathrm{M}$ and Sri R Rajagukguk. "Upaya Meningkatkan Kemampuan Pemecahan Masalah Matematika Siswa Dengan Menggunakan Model Pembelajaran Problem Based Learning Di Kelas X SMA". Jurnal Inspiratif, vol. 3, no. 2, 2017, h. 117.

Purwasih, R. "Peningkatan Kemampuan Pemahaman Matematis dan Self Confidence Siswa MTS di Kota Cimahi Melalui Model Pembelajaran Inkuiri Terbimbing." Jurnal Didaktik, vol. 9, no. 1, 2015, h. 16-25.

Sari, Indah Puspita. "Meningkatkan Kemampuan Pemecahan Masalah Matematis Siswa SMP Melalui Pendekatan Problem Posing." Jurnal Didaktik STKIP Siliwangi Bandung, vol. 9, no. 1, 2015, h. 1015.

Slavin, Robert E. Cooperative Learning Teori, Riset Dan Praktik. Bandung: PT Nusa Media, 2015.

Windari, Fimatesa, et al. "Meningkatkan Kemampuan Pemecahan Masalah Matematika Siswa Kelas VIII SMP N 8 Padang Tahun Pelajaran 2013/2014 Dengan Menggunakan Strategi Pembelajaran Inkuiri." 
Desimal, 1 (3), 2018 - 302

Sri Maryanti

Jurnal Pendidikan Matematika, vol.

3, no. 2, 2014, h. 25-28.

Yulian, Vara Nina. "Meningkatkan Kemampuan Pemecahan Masalah Matematis Siswa Melalui Metode Pembelajaran Metode Inkuiri Berbantuan Software Algebrator". JPPM, vol. 9, no. 1, 2016, h. 20-24. 